\title{
社会資本整備を内包した経済成長モデルの構造パラメータ推定*
}

\section{Estimation of the Structural Parameters of Economic Growth Model with Social Infrastructure *}

\author{
加藤裕人 $* *$ 宮城俊彦 $* * * \cdot$ 仲原由布子 $* * * *$ \\ By Hiroto KATO** - Toshihiko MIYAGI*** - Yuko NAKAHARA****
}

\section{1.はじめに}

三井・太田 ${ }^{1)}$ ，吉野・中島 ${ }^{2)}$ を始めとして社会資本 整備の経済効果に関する研究はわが国でも数多く行われ てきた. これらの既存研究成果や手法は江尻・奥村・小 林 ${ }^{3)}$ で総括的レビュウが行われている. わが国を含む 世界において広く用いられてきたのが生産関数アプロー チである。この手法の問題は, 社会資本の蓄積が経済成 長を促すと同時に，経済成長率の大小が公共投資に影響 を与えるという，間接的フィードバック効果を構造化で きないという点である. この因果関係を時系列データに 見出そうとするのがVector Auto Regressive(VAR)アプロ 一チであり, Annala et.al ${ }^{4)}$ はVARモデルを用いて日本 経済の成長分析を行っている，VARは，資本が毎期の 投資とストックの減耗の結果として蓄積されるというフ イードバック構造を持ち, 社会資本が有する長期的な生 産力効果を取り込める利点をもつ。しかし，VARモデ ルは, 経済の時系列データに存在する因果関係を指摘で きるのみで，ミクロ経済論的基礎付けをもたないという 欠点をもつ. 理論的裏付けがなくデータ上の経験則に基 づくだけのモデルは, 現実経済の変動を経済理論に立脚 した形で説明することができず，経済ショックに起因す る変動に対して不安定となる場合も起こりうる. この場 合, 安定に向かう力が経済には内包されていると考える 方が妥当である. 一方, Solow $^{5)}$, Aschauer ${ }^{6)}$ などは経 済成長の最大の要因は全要素生産性(TFP), または技術 進歩や人的資本にあると述べている.

こうした背景を受け，本研究ではまず，ミクロ経済 理論を基礎に展開された経済成長モデルを対象に, 技術 進歩や人的資本を取り込んだ経済成長モデルを提案する. そして，それをVARモデルの利点を内包したモデルに 拡張する.VARモデルを組み込むことの利点は, 経済

*キーワーズ : 計画基礎論，計画手法論，公共事業評価法 **学生員, 東北大学大学院情報科学研究科

(宮城県仙台市青葉区荒巻字青葉6-6-6,

TEL:022-795-7495, E-mail:kato@plan. civil. tohoku. ac. jp) $* * *$ 正員, 工博, 東北大学大学院情報科学研究科 *****非会員, 東北大学大学院情報科学研究科
成長モデルの構造パラメータを時系列データから推定で きる点にある.これによって, 経済成長モデルで標準的 に用いられるパラメータではなく, わが国の経済成長に 時系列データを反映した形で, 社会資本整備が経済成長 に与える効果を計測することを目的とする.

本研究の構成は以下のようである。 まず， 2 章では 本研究の基礎となる経済成長モデルの背景を概要する. 続く 3 章では「分割できない労働」を仮定したHansen ${ }^{7)}$ のReal Business Cycle(RBC)モデルを基礎として，民間資 本・人的資本・社会資本ストックを区別したモデルの定 式化を示す．4章では，3章で提案されたモデルの均衡 条件を線形ダイナミック・システムとして状態空間表現 し，観測方程式に1次の自己回帰誤差ベクトルを組み合 わせた, いわゆるhybrid型状態空間表現8) を行う. 最後 に, 日本の長期時系列データを用いて, 提案するモデル の構造パラメータを最尤法により推定し, 社会資本の生 産弾力性の計測及びモデルの特性分析を行う。

\section{2. モデルの特徵}

本研究では, 以下のような想定の下にモデルの構築 を行った.

（1）経済主体は無期限期間生存可能な代表的個人を想定 する. 代表的個人は家計であり企業を所有・経営す ると同時に，政府としての役割を担うとする．また， RBCモデルでは全要素生産性のショック，ここで は技術ショックにより景気循環が起きると想定して いる，RBCモデルは，家計などミクロ経済主体の 行動が, 将来を見越しての最適化行動の結果として 扱われるため, ミクロ的基礎付けを持つという点で Lucas ${ }^{9)}$ の批判の対象外となる.

(2) Hansen ${ }^{7)}$ によって提案された「分割できない労 働」を仮定する. Hansenは労働者一人当たりの労働 時間を外生とおき, 労働者数のみの変動によって総 労働時間数が変動すると仮定した. この仮定の下で は，家計は1期ごとに自身の労働時間の代わりに働 く確率を選択する.このとき, 労働者の総労働時間 は企業によって予め決められていて, 個々人はフル タイム働くかまたは全く働かないかのどちらかしか 
選択できない.この仮定は労働時間の調整が主に雇 用・解雇によって起きているという観測に基づいた ものであり, Hansenは米国の労働の変動をRBCモ デルによって説明できることを示した．現在では日 本においても, Hansenモデルが標準的なRBCモデ ルとして, Hayashi and Prescott ${ }^{10)}$ によって位置づけ られている.

(3) 時系列データから成長会計を行った研究の中で, 経 済成長のほとんどは全要素生産性の上昇率によって 説明できると分析している例は多い，資源の乏しい 日本において，全要素生産性を上昇させることが中 長期的な経済成長に必要不可欠である，全要素生産 性は労働と資本以外の要素が経済成長に与える効果 を表現しており，全要素生産性が具体的にどういう 項目で構成されるかの明確な定義はない，一つの有 力な見方が人的資本の影響である. 特にわが国にお いては人的資本の蓄積が，全要素生産性を上昇させ る大きな要因と考えられる，人的資本を扱った代表 的なモデルとしてUzawa-Lucasモデル11）12）が挙げ られる. Uzawa-Lucasモデルにおいて，人的資本の 生産関数に規模の経済性を考慮する必要があるとし, モデルを拡張させたのがGong et.al ${ }^{13)}$ である. 彼ら は人的資本の代理変数として，教育支出を用いてい る. 本研究では，Gongモデルを参考に人的資本の 生産関数を導入しているが，政府消費支出と公共投 資を投入要素としている点でGongモデルとは異な っている.

\section{3. モデルの定式化}

本章では，期待值オペレータを $E_{0}$ ，主観的割引率を $\rho$ として，以下の無限期間生存可能な代表的個人の生 涯期待効用最大化問題を考える.

$$
\begin{aligned}
& \max . E_{0} \sum_{t=0}^{\infty} \rho^{t} U\left(C p_{t}, C g_{t}, L_{t}\right) \\
& \text { s.t. } \quad Y_{t}=A_{t} K_{t}^{\alpha} H_{t}^{\beta} G_{t}^{\gamma}\left(\eta^{t} L_{t}\right)^{1-\alpha-\beta-\gamma} \\
& Y_{t}=C p_{t}+C g_{t}+I p_{t}+I g_{t} \\
& K_{t+1}=I p_{t}+\left(1-\delta_{K}\right) K_{t} \\
& H_{t+1}=\left(C g_{t}\right)^{\psi_{1}}\left(I g_{t}\right)^{\psi_{2}}+\left(1-\delta_{H}\right) H_{t} \\
& G_{t+1}=I g_{t}+\left(1-\delta_{G}\right) G_{t} \\
& \ln A_{t}=(1-\omega) \ln A+\omega \ln A_{t-1}+\varepsilon_{t} \\
& \varepsilon_{t} \sim N\left(0, \sigma^{2}\right), \operatorname{cov}\left(\varepsilon_{i}, \varepsilon_{j}\right)=0 \quad(i \neq j)
\end{aligned}
$$

変数はそれぞれt期における 1 人当たりの值であり, $Y_{t}$ : 生産, $C p_{t}$ : 民間消費, $C g_{t}$ : 政府消費, $I p_{t}$ : 民 間投資， $I g_{t}$ : 公共投資， $K_{t}$ : 民間資本ストック， $H_{t}$ : 人的資本ストック, $G_{t}$ : 社会資本ストック,
$L_{t}$ : 労働時間, $A_{t}$ : 技術進歩過程である. ここで, 先 決変数は, $H_{t}, G_{t}, A_{t}$, 非先決変数（コントロール変 数) は $Y_{t}, C p_{t}, C g_{t}, I p_{t}, I g_{t}, L_{t}$ であり, このモデルにお けるforward-looking変数は $C p, C g, I g$ である.

代表的個人の効用関数は式(8)のように表される

$$
U\left(C p_{t}, C g_{t}, L_{t}\right)=\ln C p_{t}+\mu \ln C g_{t}-\tau L_{t}
$$

この効用関数において, 政府消費支出のうち公共サービ 又等も効用増加をもたらすと想定している点が既存の $\mathrm{RBC}$ モデルと大きく異なる。代表的個人は変数

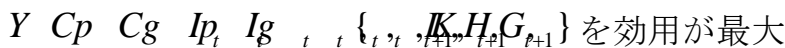
となるように各期で決定する． $\mu, \tau$ は効用に関する パラメータであり，「分割できない労㗢」の仮定の下では, 労働時間は効用に対して線形となる. 式(2)の生産関数 はコブ・ダグラス型で規模に関して収穫一定とし，各資 本ストックの係数は $\alpha, \beta, \gamma$, パラメータ $\eta$ は労働増加 的技術進歩である。式(3)は，予算制約式である。すな わち，生産が家計の所得であり，そこから消費，税金を 差し引いた分が貯蓄に充てられる，貯蓄はすべて民間投 資に回されるとする．人的資本は式(5)のように，政府 消費と公共投資によって生産され，前期の人的資本ス卜 ック差し引き分を加えたものが当期の人的資本ストック を構成する. $\delta_{K}, \delta_{H}, \delta_{G}$ は各資本の固定資本減耗率で あり， $\psi$ は人的資本の規模に関する収穫聥減を発生さ せるパラメータである．技術進歩過程を表す式(7)は1次 の自己回帰過程とし，A は定数項， $\omega$ は1次の自己回 帰パラメータ, 確率的誤差項 $\varepsilon_{t}$ はガウス白色雑音とす る. 代表的個人はこの過程を知っており，これをもとに 当期のショックを受けて，来期のショックを予想しなが ら今期の計画を立てるとする.

\section{4. ハイブリッド・モデルと構造パラメータ推定法}

（1）ハイブリッド・モデル

3. で定式化したモデルを標準的なRBCモデルの解 法 ${ }^{14)}$ に従い，合理的期待解を求める.

a) 代表的個人の最適化問題を解き，均衡条件式を導 出する.

b) 各変数をワで除してトレンドを除去しあと，モデル の定常状態を算出する.

c) 確率的非線形差分方程式である均衡条件式を定常 状態近傍で対数線形近似を行う。

d) Blanchard-Kahn条件 ${ }^{15)}$ を適用し，均衡条件式を状 態空間表現する.

結果として得られる均衡条件の状態空間表現は式(9)の ようになる. 


$$
\begin{aligned}
& s_{t+1}=\Pi(\theta) s_{t}+B \varepsilon_{t+1} \\
& f_{t}=U(\theta) s_{t}
\end{aligned}
$$

ここで，ПとUはモデルの構造パラメータ $\theta$ 関数で 表されるシステム行列であり, 状態ベクトル $s_{t}$, 観測 ベクトル $f_{t}$, 行列 $B$ は以下のようになる.

$$
\begin{gathered}
s_{t}=\left[\begin{array}{lllll}
k_{t} & h_{t} & g_{t} & a_{t}
\end{array}\right]^{\prime} \\
f_{t}=\left[\begin{array}{llllll}
y_{t} & c p_{t} & c g_{t} & i p_{t} & i g_{t} & l_{t}
\end{array}\right]^{\prime} \\
B=\left[\begin{array}{llll}
0 & 0 & 0 & 1
\end{array}\right]^{\prime}
\end{gathered}
$$

ただし, 対数線形化後の変数は, 定常状態からの乘離率 を表しており，それぞれ小文字で表記している．次に， $i p_{t}$ は予算制約条件式加他の変数の残差として求めら れるので，観測べクトル $f_{t}$ から $i p_{t}$ を除き，式(13)に置 き換え，新たに式(14)のような状態空間表現にする。

$$
\begin{gathered}
d_{t}=\left[\begin{array}{lllll}
y_{t} & c p_{t} & c g_{t} & i g_{t} & l_{t}
\end{array}\right]^{\prime} \\
{ }_{t+1} \quad s D\left(\Theta \theta_{t} B \varepsilon_{t+1}\right. \\
{ }_{t}=\operatorname{ads}
\end{gathered}
$$

モデルの状態空間表現(14)において，行列Cは行列Uか ら，i $p_{t}$ に関する行を除いた行列である。ささらに，観測 方程式に式(15)のような1次の自己回帰誤差べクトル $v_{t}$ を加えて，式(16)のように変形する.

$$
\begin{aligned}
& v_{t+1}=D v_{t}+\xi_{t+1} \\
& d_{t}=C(\theta) s_{t}+v_{t}
\end{aligned}
$$

ここで，ベクトル $\xi_{t}$ は期待值ゼロ，共分散行列 $\mathrm{V} の$ 白 色雑音であり，技術ショックの確率的誤差項 $\varepsilon_{t}$ とは無 相関と仮定する．観測方程式に誤差項を付け加える方法 は，Sargent ${ }^{16)}$ などでも扱われているが，そこでは系列 相関しない誤差項を取り扱っている。，一方，系列相関す る誤差項を想定し一般的なVARとすることで，モデル がデータ間の変動や連動性を捉える際の制限がなくなり, より柔軟性が生じると Ireland ${ }^{8)}$ は述べている。この状態 空間表現をIrelandによるhybrid型状態空間表現と呼ぶ。 この表現にすることにより，カルマンフィルタを用いて 状態推定を行うことが可能となる.

次に，状態変数ベクトルと誤差ベクトルを新たに次 式のように定義する.

$$
\mathrm{x}_{t}=\left\lfloor\begin{array}{c}
s_{t} \\
v_{t}
\end{array}\right\rfloor \quad \eta_{t+1}=\left\lfloor\begin{array}{c}
B \varepsilon_{t+1} \\
\xi_{t+1}
\end{array}\right\rfloor
$$

そして，式(14)の状態空間表現を式(18)のように変形 する.

$$
\begin{aligned}
& \mathrm{x}_{t+1}=F(\theta) \mathrm{x}_{t}+\eta_{t+1} \\
& d_{t}=G(\theta) \mathrm{x}_{t}
\end{aligned}
$$

ただし， $\eta_{t}$ は以下に定義する共分散行列持つ白色雑音 である。

$$
\begin{aligned}
& \eta_{t+1} \sim N(0, Q), \operatorname{cov}\left(\eta_{i}, \eta_{j}\right)=0 \quad(i \neq j) \\
& Q=E\left(\eta_{t+1} \eta_{t+1}^{\prime}\right)=E\left(\left\lfloor\begin{array}{c}
B \varepsilon_{t+1} \\
\xi_{t+1}
\end{array}\right]\left[\begin{array}{ll}
\varepsilon_{t+1}^{\prime} B^{\prime} & \xi_{t+1}^{\prime}
\end{array}\right]\right) \\
&=\left[\begin{array}{cc}
B E\left(\varepsilon_{t+1} \varepsilon_{t+1}^{\prime}\right) B^{\prime} & B E\left(\varepsilon_{t+1} \xi_{t+1}^{\prime}\right) \\
E\left(\xi_{t+1} \varepsilon_{t+1}^{\prime}\right) B^{\prime} & E\left(\xi_{t+1} \xi_{t+1}^{\prime}\right)
\end{array}\right] \\
&=\left[\begin{array}{cc}
B \sigma^{2} B^{\prime} & 0 \\
0 & V
\end{array}\right]
\end{aligned}
$$

（2）構造パラメータの推定法

構造パラメータの推定には，最尤法を用いる。しか し，式(18)の状態空間モデルには観測值を得ることがで きない変数も含まれている，特に，資本ストックは一般 にはデータとして蓄積されているわけではない。無論, 推定された社会資本ストックを観則值として代用するこ とも可能であるが，本研究では資本ストックを，カルマ ンフィルタを用いて推定する手法を用いる. カルマンフ イルタによって状態変数の推定誤差を最小にするように 状態変数に含まれる潜在変数を求めることができるので 最尤法によってシステム行列，観測行列に含まれる構造 パラメータを推定することが可能になる.

データ期間を $T$ とすると，対数尤度関数は式(20)のよ うに与えられる。

$$
\ln L=-\frac{3 T}{2} \ln (2 \pi)-\frac{1}{2} \sum_{t=1}^{T} \ln \left|F_{t}\right|-\frac{1}{2} \sum_{t=1}^{T} u_{t}^{\prime} \ln F_{t}^{-1} u_{t} \text { (20) }
$$

対数尤度関数に含まれる観測ベクトルの推定誤差 $u_{t}$ と観測誤差共分散 $F_{t}$ はカルマンフィルタの更新方程式 で逐次計算される.

\section{5. 推定結果と考察}

（1）使用データ

使用寸るデータは1970年第1四半期〜2005年第3四半 期の我が国のマクロ経済データであり，内閣府社会経済 研究所・国民経済計算データから民間最終消費支出，政 府最終消費支出，民間固定資本形成，公的固定資本形成 額を用いた。值は平成 2 暦年固定基準年方式の実質值で あり，季節調整済である．生産額は式(3)の予算制約式 に従い4変数の合計值として求めた．平均総労働時間は 厚生労働省・労働統計データを使用し，各変数を 1 人当 たりの值にするため総務省統計局の15歳以上人口を用い 
てそれぞれ与えた．また，サンプル期間内に民営化され た日本電信電話公社と日本国有鉄道はその公的な企業性 質を考慮して, 公的部門に留まるように企業設備投資額 の調整を行った，その際，経済産業省企業金融調査のデ 一タを参考にした.

(2) 構造パラメータの推定結果

モデルの構造パラメータの初期值として, 資本ストッ クの係数, $\beta, \gamma$ 以外のパラメータは使用データを下に 計算した数值を用いた. 資本ストックの係数に関しては, 民間消費，民間投資，政府消費，公共投資，生産の定常 状態の值を求め, 現実の経済の構成比に近くなるように $\alpha, \beta, \gamma$ を求めた. 1 次の自己回帰誤差ベクトルの初期值 設定はIrelandの方法を参考に以下の手順で行う.

a) $\mathrm{D} ， \mathrm{~V}$ とに対角行列として作ったモデルで推定を 行う.

b) a)で得られた值でVARを構筑する.

c) VARの誤差共分散行列をコレスキー分解する.

d) b)で求められた行列Dを初期值として用い, c)で求 められたコレスキー分解後の下三角行列をV $の$ 初期 值とする.

e） Dの最大固有值の絶対值が1以下で，コレスキー分 解後の行列の積が対称な半正定值行列であるかの判 定を行う.

以上を初期值として最尤法により得られたパラメー 夕推定結果は表ー 1 に示す。ここでは, 誤差ベクトルの パラメータは割愛した。 また, 時間的割引率 $\rho$ と労働 増加的技術進歩 $\eta$ は信頼できる推定值を得ることがで きなかったため，推定対象から除外し，新たに $\rho=0.99, \eta=1.0051$ という值を Ireland ${ }^{8)}$ を参考に設 定して推計を行った.

\begin{tabular}{|c|c|c|}
\hline パラメータ & 推定值 & 標準誤差 \\
\hline$\alpha$ & 0.253 & 0.00475 \\
\hline$\beta$ & 0.0948 & 0.00439 \\
\hline$\gamma$ & 0.134 & 0.00560 \\
\hline$\mu$ & 0.296 & 0.00306 \\
\hline$\tau$ & 0.0048 & 0.000383 \\
\hline$\psi_{1}$ & 0.595 & 0.00386 \\
\hline$\psi_{2}$ & 0.188 & 0.00708 \\
\hline$\delta_{K}$ & 0.0274 & 0.000425 \\
\hline$\delta_{H}$ & 0.0136 & 0.000246 \\
\hline$\delta_{G}$ & 0.0298 & 0.000505 \\
\hline$A$ & 0.738 & 0.00385 \\
\hline$\omega$ & 0.944 & 0.00588 \\
\hline$\sigma$ & 0.0073 & 0.00022 \\
\hline
\end{tabular}

(3) パラメータに関する考察

社会資本の生産弾力性として0.134を得た。コブ・ダ グラス型の生産関数を用い，全国時系列データを用いた 既存研究 17)-19) では0.22 0.25という值を得ている.こ れらと比較すると小さい值となった。 しかし，これらの 既存研究の推計期間は1956 1989年の範囲であり, 資本 ストックの経済成長一の影響が比較的大きい時代を対象 にしている，また，人的資本ストックが含まれていない ので単純には比較できない．また，設定状況が異なるが， 本研究と推計期間が比較的近い研究例として, 1974 1998年のデータを用いた唐木ら ${ }^{20)}$ の分析がある。 生産関数法を用いたこの分析では，大都市雇用圈と地方 都市圈を分類しているが，比較的大き目の值を得た大都

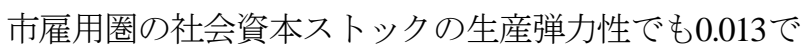
あった。社会資本ストックの限界生産性は1970年を境と して伸び率が鈍化したという報告」もある ${ }^{17)}$ ．社会資 本ストックの経済成長への影響が以前ほど顕著でないこ とは確かであろうが，資本ストックが果たす長期的な生 産力効果を取り込めていない可能性もある.

本研究で推定された資本ストックの係数に近い值を 与えている研究としてCanning ${ }^{21)}$ がある. 彼は物的資 本の生産弾力性 0.37 , 人的資本の弾力性 0.08 という結果 を得ている. Canningは民間資本，人的資本，社会資本 を用いて先進国，発展途上国別の推計・分析も同時に行 っているが，特徴的なのは社会資本ストックを電話回線 数, 舗装道路長, 線路長, 電力供給量などの分野別の物 理データを用いて推計を行っている点である。

人的資本の生産弾力性を計測した既存研究は数多く あるが，基本的に観測できない変量であるため推計方法 が各研究によって大きく異なり，值にもばらつきが大き い. 本研究の值をこれらの既存推計值と照らし合わせる と，宋 ${ }^{22)}$ の約 0.4 という值に比べると大幅に小さく, Klenow and Rodriguez-Clare ${ }^{23)}$ やHall and Jones ${ }^{24)}$ の約 0.1 に近い值となっている.

固定資本減耗率に関して, Kydland and Prescott ${ }^{25)}$ は, 減耗率を 0.025 と設定しているが，この值は年間 $10 \% の$ 減耗を表しており，物的資本ストックにおいて適当な值 であるとしている。一般に，RBCモデルにおいては， 物的資本ストックの四半期減耗率として，0.01〜0.025の 範囲の值が多く用いられている ${ }^{13)}$ 。本推定では，民間 資本ストックの減耗率 $\delta_{K}$ は 0.0274 , 社会資本ストック の減耗率 $\delta_{G}$ は0.0298であり，標準的RBCモデルで仮定 される值に近い值を得ている.

$A$ と $\mu$ は均衡条件式に表れず，システムの動的特性 に影響を与えないパラメータである.これらはモデルの 定常状態にのみ関与している. 推定された $A$ と $\mu$ を用 いてモデルの定常状態を求めたところ，民間消費，民間 
投資，政府消費，公共投資が現実のGDP構成比に近い 定常值をとることを確認した.

$\sigma$ は技術ショックの大きさに関するパラメータであ るが，0.0073といら值は既存のRBCモデルで用いられて いる值よりも大きい. 対して，技術ショックの自己回帰 パラメータ $\rho$ は, 他のモデルに対して小さい值となっ た. このことから, 推計期間の日本の全要素生産性また は技術ショックの持続性は高くなく, ショックの大きさ にもばらつきがあるということがいえる.

（4）インパルス反応分析

外生的ショックに対するモデルのシミュレーション を行い，モデルの特性を分析する. 図ー 1 は+0.1の技術 ショックを与えた時の, 各变数の定常状態からの乘離率 を表していて, 横軸の時間軸の単位は四半期である.

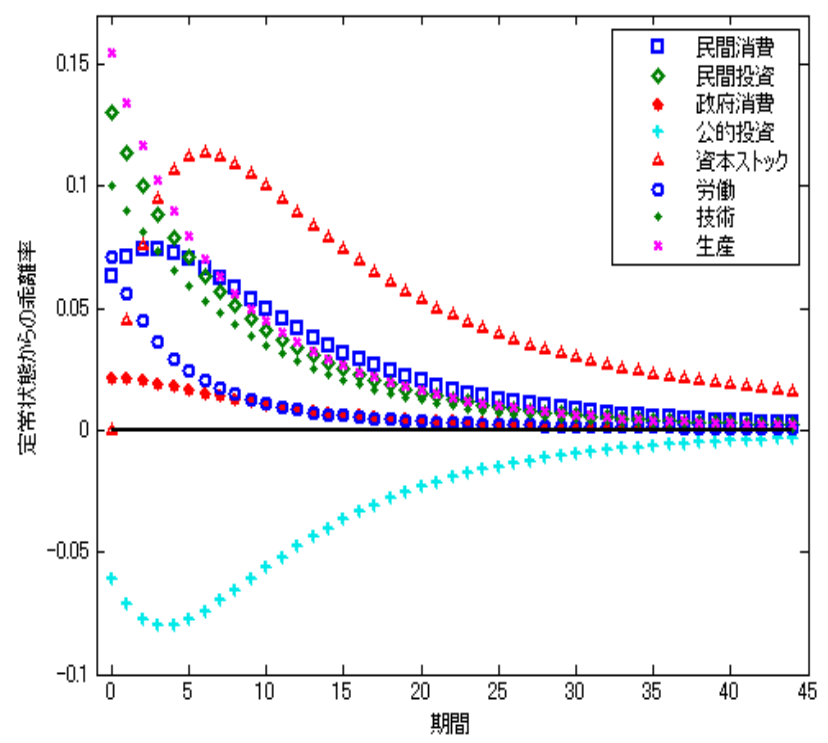

図-1＼cjkstart各変数のインパルス反応

技術ショックに対する各変数の反応の特徴は以下の 通りである.

- 生産はショックと同時に高い反応を示し, 1番大き い值をとる．技術ショックの減少とともに生産も 減少し収束に達する.

- 民間投資は生産と高い相関関係にあり，その反応 も大きい.

・ 民間消費の反応のピークはショックが与えられて から遅れて現れ, その後も高い水準を保っている. 家計は消費の変動を好まないので, 生産所得の増 分を長い期間にわたり少しずつ分割して消費する という傾向をもつ.これは消費の平滑化と呼ばれ る性質で, foward-looking変数に見られる特徴であ る. 同様の性質をfoward-looking変数である政府消 費，公共投資も有している.
・ 政府消費は正の反応を見せるが，その大きさは他 の変数と比較してわずかである.

- 公共投資は唯一負の反応を示寸．この反応は，公 共投資は生産と負の相関関係にあるという日本の 現実データにあてはまる，日本において，公共投 資は不況時に増加し, 好況の時減少する傾向にあ るので，現実の特徴をこのモデルは捉えている.

また，公共投資の変動がピークに達するのが4，5 期目，つまりショックが起きてから約1年後であり， 予算が反映されるまでの時間差と考えられる.

- 労働時間は正の反応を示寸が, 他の変数と比べて 減少が早い。これは一般に, 生産が上昇した際, 生産性が高い時期に労働供給を増やした方がより 多くの生産が見込めるので, 一時的に労働供給が 増えるためである. また, 生産の上昇で所得が増 え, 働く必要性が低下したためとも考えられる.

・3つの資本ストックはショック時の変動は起きない が，時間遅れを持って増加に転じる．また，他の 変数は50期以内に0に収束しているが，資本ストッ クだけ収束に至っていない，そこで，資本ストッ ク別のインパルスレスポンスをみると，図一2の ようになる，民間資本ストックと人的資本ストッ クはピークが同時期に現れ，民間資本ストックが1 番大きな反応を示している. 対して, 社会資本が とる最大值は小さく，ピークの時期も遅いが，そ の後の減少は緩やかである. 最大值の大きさは公 共投資が負の反応を示していることが影響してい ると考えられる.これらの反応から確認できるの は，社会資本ストックは効果が表れるまでに比較 的時間を要するが, 社会基盤は一旦整備が行われ ると, その効果は長い期間にわたって持続すると いうことである。

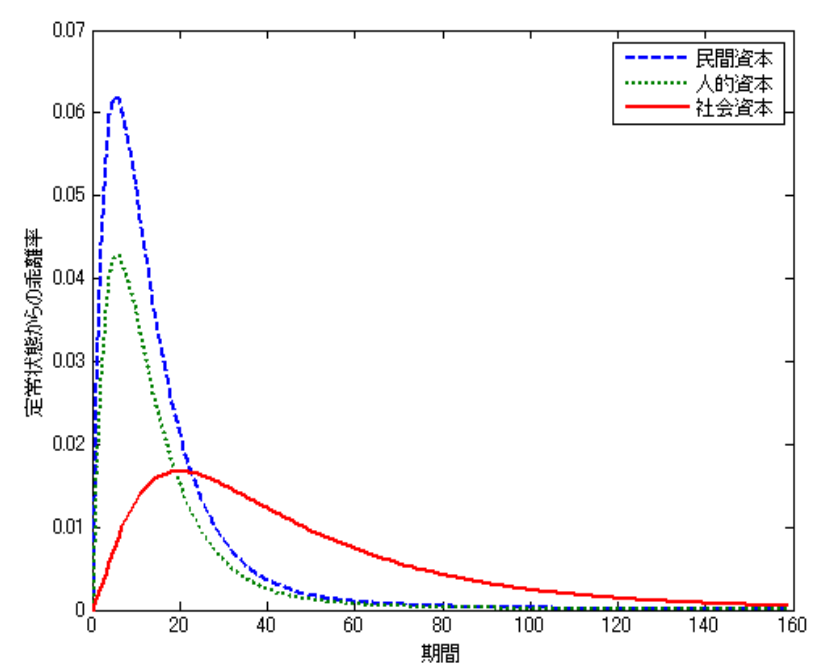

図一2 各資本ストックのインパルス反応 
（5）予測の正確度

本モデルを評価するために，本モデルとVARモデル を用いて生産の1期先予測を比較する. まず，1970年第1 四半期から1989年第4四半期までの期間を教師データと してパラメータを推定し，そのパラメータを用いて教師 データ以降の 1 期先予測をカルマンフィルタによって与 える，予測の当てはまり度を，VARモデルと比較して モデルの再現性について分析する。いわゆる「失われた 10年」を含む1990年以降の日本の生産をそれぞれのモデ ルがどの程度再現できるのかを確かめる。それぞれの予 測值と現実值を表したのが図ー3，図一4である.

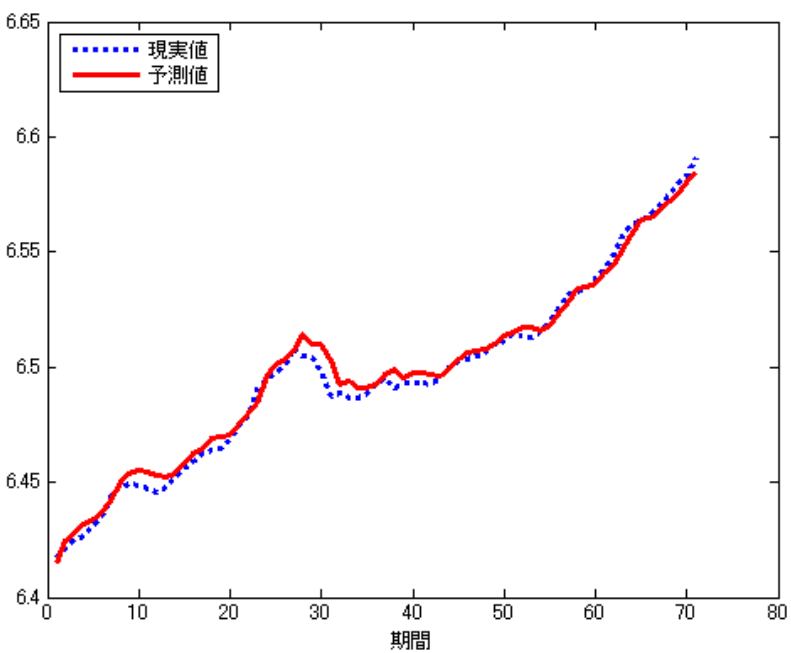

図ー3＼cjkstart本モデルによる生産の1期先予測

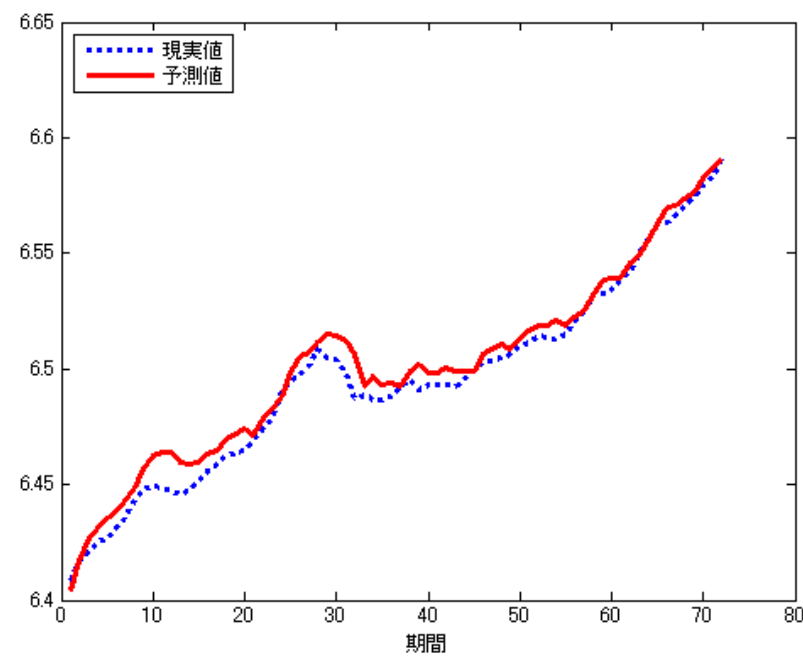

図ー4 $\operatorname{VAR}(1)$ モデルによる生産の1期先予測

日本経済の停滞期を予測しているため，全モデルで 生産を過大に予測してしまう傾向にある. 特に10期付近 のバブル景気及び30期付近に起きたアジア通貨危機の後 は現実值を的確に捉えることができていない．やはり， 何らかのショックによるデータ上の突然の変化，いわゆ るトレンドブレイクが発生するとどのモデルも予測值が
大きくはずれる傾向にある.

次に，本モデルとVAR(1)モデルの予測誤差の比較を 行う。比較の指標としてDiebold and Mariano ${ }^{26)}$ によっ て定義された式(21)のような予測誤差の平方差である $l_{t}$ を用いる。

$$
l_{t}=\tilde{v}_{t}^{2}-\tilde{r}_{t}^{2}
$$

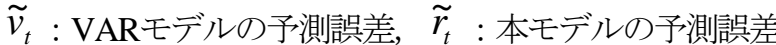

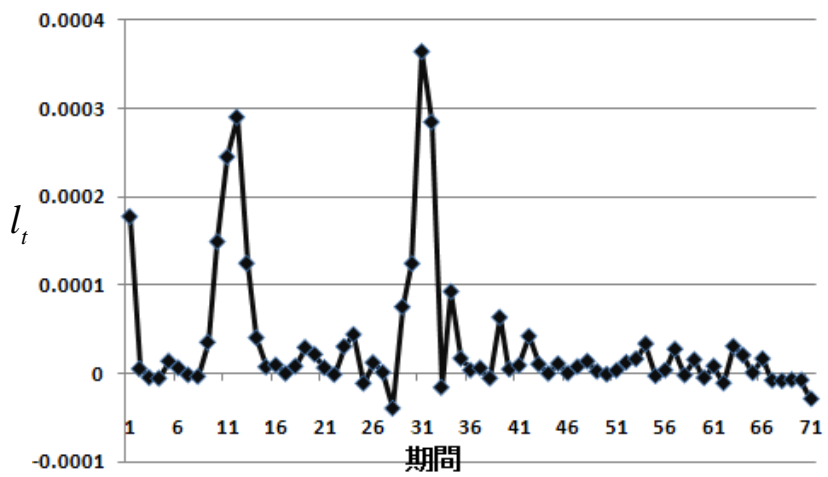

図-5 予測誤差の比較 : $l_{t}$

$l_{t}$ を図示すると図一 5 のようになる，図は， $l_{t}$ の值 が正で，かつ大きいほど，本モデルの推定誤差が小さい ことを表している．この結果より，本モデルの方が予測 の再現性は高いといえる. 図の10期目と30期目付近は現 実の時系列データにトレンドブレイクが起きている時点 であるが，こうした変化に本モデルの方が上手く適応で きていることも読み取ることができる，すなわち，経済 均衡を内包し，forward-looking変数を導入したことの効 果が現れている。このように，「失われた10年」を含む日 本の1990年以降をVARモデルで計測すると誤差が大き く現れてしまう。特に，1次のVARでは大きく予測が 外れてしまう。また，この期間をVARモデルよりも上 手く予測できたのは，本モデルに「分割できない労㗢」の 仮定をおいていることも一因と考えられる。つまり，こ の期間の労働時間は雇用・解雇によって調整されていた という見方ができる．さらに，トレンドブレイクが起き ていない 40期以降でも本モデルの予測の方が優れている のが確認できる.

また, Diebold and Mariano ${ }^{26)}$ によって提案された, 予測精度を比較するための式(22)のような統計量 $S$ を用 い，統計的検定を行った.

$$
\begin{gathered}
S=l / \sigma_{l} \\
l: l_{t} \text { の平均值, } \quad \sigma_{l}: l \text { の標準誤差 }
\end{gathered}
$$

この統計量 $S$ が正のとき，本モデルの予測が優れてい ることを表し，負のときはその反対である。ここで，帰 無仮説を本モデルの予測誤差とVAR(1)またはVAR(2)の 予測誤差が等しいと立てる，検定の結果，VAR(1)と VAR(2)の両方とも有意水準1\%で棄却された。つまり， 
本モデルの方が生産の 1 期先予測が優れているというこ とが示された。

以上より, 本モデルはVARモデルと比較して, デー タ上のトレンドブレイクに対応した説明力のある予測が 行え, 再現性も高いことが確認された.

（6）固定パラメータの安定性

本研究で用いた推計法はパラメータを時間によらず一 定とおいた，いわゆるパラメータの定常性を仮定してい る. しかし, 一般的に, 経済状況の変化とともにパラメ 一タの值は変動すると考えるのが自然である.ここでは 本モデルにおける固定パラメータの安定性を調べるため, 1990年を境に二つのサンプル期間に分けてパラメータを 推定し, 固定パラメータの安定性に関する仮説検定を行 った. 帰無仮説を二つのパラメータセットが等しいとし, Andrew and Fair ${ }^{27}$ によって提案されたパラメータの安 定性を調べるWald検定を行ったところ, 帰無仮説は棄 却された，その有意水淮は1\%である。この結果は1990 年を境に経済状況は変化したことを示唆しており，また， 本分析に固定パラメータを用いたことは適切とはいえな いということを示している.

\section{6. おわりに}

本研究では，社会資本整備が経済成長に与える効果を 分析するため, 両者の因果構造の把握を目的としてモデ ルを構築し，マクロ経済データを用いてモデルの未知パ ラメータの推定を行った. 扱ったモデルは民間資本，人 的資本，社会資本ストックの3資本ストックを内生化し， 「分割できない労働」の仮定をおいたRBCモデルである. モデルの評価としては, パラメータの值自体に関しても, インパルス反応分析や予測精度の面からも, 現実の経済 の動向を概ね説明できているので, 妥当なモデルを構築 できたと判断した. また, 動学的マクロ経済モデルの状 態空間表現に自己回帰寸る誤差を取り入れたhybrid型状 態空間表現にすることで, VARアプローチよりもデー タに当てはまりのよい計測を行えることが示された，そ して, 本モデルは経済均衡を内包し, 全要素生産性を含 めた経済成長のメカニズムを特定化しているので, 社会 資本がもつ長期のストック効果を取り込むことができた と思われる. 得られた社会資本の生産弾力性は既存研究 と推計期間や方法が異なるため単純に比較は行えないが, 社会資本の生産力効果は1970年以降低下しているとの報 告 ${ }^{19)}$ も踏まえ, 社会資本ストックの実情を反映した值 が得られたと考えられる. また，インパルス反応分析に より，技術ショックに対して社会資本は長期間にわたり 正の反応を持続することが確認された. 寸なわち, 生産
性の上昇が長期の社会資本ストックの蓄積に影響を及ぼ しているということである. このとき，民間資本・人的 資本ストックと比較して反応が小さいという面もあるが, 公共投資が負の反応を示すことが影響を及ぼしている.

今回, 推定值が大きく外れたパラメータが存在した ということがまず問題点の一つとして挙げられる.これ は, 本来必要な経済変数が久落し, 経済環境を限定して 設定しているためである. また，パラメータの安定性に 関する検定から，固定パラメータの限界が判明した.つ まり，時変パラメータを導入することが必要となる．こ れらの改善及びモデルの精緻化などが残された研究課題 である.

\section{参考文献}

1) 三井清, 太田清編著: 社会資本の生産性と公的金融, 日本評論社, 1995 .

2）吉野直行，中島隆信編 : 公共投資の経済効果，日本評 論社, 1999.

3）江尻良，奥村誠，小林潔司：社会資本の生産性と経済 成長:研究展望, 土木学会論文集, No.688/IV-53, pp.75-87, 2001.

4) Annala, C.N., Batina, R.G. and Feehan, J.P.: Empirical impact of public infrastructure on the Japanese economy, The Japanese Economic Review, Vol. 59, N0.4, pp.419-37, 2008.

5) Solow, R.M..: A contribution to the theory of economic growth, Quaterly Journal of Economics, Vol.70, pp.65-94, 1956.

6) Aschauer, D.A.: Is public expenditure productive?, Journal of Monetary Economics, Vol.23, pp.177-200, 1989.

7) Hansen,G.D.: Indivisible labor and the business cycle, Journal of Monetary Economics 16, pp.309-27, 1985.

8) Ireland, P.N.: A Method for Taking Models to the Data, Journal of Economic Dynamics and Control, Vol.24, pp.1205-26, 2004.

9) Lucas, R.: Econometric policy evaluation:A critique, Carnegie-Rochester Conference Series on Public Policy 1, pp.19-46, 1976.

10) Hayashi, F. and Prescott, E.C.: The 1990s in Jaapan:A Lost Decade, Review of Economic Dynamics,5(1), pp.206-35, 2002.

11) Uzawa, H.: Optimum technical Change in an Aggregate Model of Economic Growth, International Economic Review, Vol.6, pp.18-31, 1965.

12) Lucas, R.E.: On the mechanics of Economic Development, Journal of Monetary Economics, Vol.22, pp.3-42, 1988.

13) Gong, G., Greiner, A., Semmler,W.: The Uzawa-Lucas 
model without scale effects:theory and empirical evidence, Structural Change and Economic Dynamics 15, pp.401-20, 2004.

14) Uhlig, H.: A toolkit for analyzing nonlinear dynamic stochastic models easily, In Marimon, R. and Scott, A. (ed), Computational Methods for the Study of Dynamic Economies, Oxford University Press, pp.30-61, 1999.

15) Blanchard, O.J. and Kahn, C.M.: The solution of Linear Difference Models under Rational Expectations, Econometrica 48, pp.1305-11, 1980.

16) Sargent, T.J.: Two models of measurement and the investment accelerator, Journal of Political Economy 97, pp.251-87, 1989.

17) 岩本康志：日本の公共投資政策の評価について，一橋 大学経済研究，Vol.41，pp.250-61，1990.

18）三井清，井上純 : 社会資本の生産性に関する研究，郵 政研究所 Discussion Paper No.1992-04， 1992.

19) 吉野直行, 中東雅樹: 社会資本の経済効果一日本の戦 後の経験一，特集:21の世紀開発途上国の社会資本を 創る，開発金融研究所報， 2000 .

20）唐木芳博, 奥原崇, 渡真利諭, 朝日ちさと, 西畑知 明 : 社会資本ストックの経済効果に関する研究一都 市圏分類のよる生産力効果と厚生効果, 国土交通政策
研究，第68号，2006.

21) Canning, D.: Infrastructure's Contribution to Aggregate Output, Policy Research Working Papers, World Bank, No.2246, 1999.

22）宋仁守: 経済発展と人的資本一日韓比較一，大阪経 大論集，第53巻，第2号， 2002.

23) Klenow, P.J. and Rodriguez-Clare, A.: The Neoclassical Revival in Growth Economics:Has it Gone Too Far?, Graduate School of Business, University of Chicago.Processed, 1997

24) Hall, R. and Jones, C.: Why Do Some Countries Produce So Much More Output Per Worker Than Others?, NBER Working Paper No.5812 .National Bureau of Economic Research, Cambridge Mass, 1998.

25) Kydland, F.K. and Prescott, E.C.: Time to Build and Aggeregate Fluctuations, Econometrica 50, pp.1345-70, 1982.

26) Diebold, F.X. and Mariano, R.S.: Comparing predictive accuracy, Journal of Business and Economic Statics 13, pp.253-63, 1995.

27) Andrew, D.W.K. and Fair, R.C.: Inference in Nonlinear Econometric Models with Structural Change, Review of Economic Studies 55, pp.615-39, 1988.

\section{社会資本整備を内包した経済成長モデルの構造パラメータ推定*}

加藤裕人 $* *$ ・宮城俊彦 $* * * \cdot$ 仲原由布子 $* * * *$

本稿では，社会資本が経済成長に与える影響を分析するために，両者の因果構造を把握することができるモ デルを提案する．ここでは動学的マクロ経済モデルであるReal Business Cycle(RBC)モデルを基礎として， 人的資本の導入や「分割できない労働」を仮定したモデルを構築し，時系列データを用いて構造パラメータの推 定を行う。その際，VARを内包するように経済成長モデルを状態空間表現し，社会資本の生産弾力性を計測す る. また，インパルスレスポンスやトレンドブレイクに対するモデルの反念分析を行う.

Estimation of the Structural Parameters of Economic Growth Model with Social Infrastructure* By Hiroto KATO** • Toshihiko MIYAGI*** • Yuko NAKAHARA****

In this paper, we propose a model that can specify causal structure between public capital and economic growth in order to analyze the impact of public capital on economic growth. We introduce Real Business Cycle (RBC) as the basis of the model and we deal with human capital and "indivisible labor" to estimate the structural parameters of the model by using time series data. Then, we use state-space representation of the model with VAR to measures the output elasticity of public capital. We analyze the impulse response and the sensitivity for the fluctuation of the data. 